\title{
Efficacy of Cellulolytic Bacteria Consortium for Composting Oil Palm Empty Bunches Containing Phytonutrients
}

\section{Potensi Konsorsium Bakteri Selulolitik Untuk Pengomposan Tandan Kosong Kelapa Sawit Yang Mengandung Fitonutrien}

\author{
Diah Nurul Aini, Tetty Marta Linda* \\ Fakultas Matematika dan Ilmu Pengetahuan Alam Universitas Riau Kampus Bina Widya \\ Pekanbaru, Indonesia, 28293 \\ *Correspondent author: +6282171265600 / tetty.martalinda@gmail.com
}

\begin{abstract}
Oil palm empty fruit bunches (OPEFB) are themost solid palm oil waste. OPEFB has often been processed into compost with the addition of certain activators. It is expected that with the addition of a consortium bioactivator composting of OPEFB can be faster and the compost produced has good nutrient content. The study aims was to determine the ability of bioactivator bacteria of cellulolytic consortium in degrading TKKS of incubation laboratory scale for 30 days. A consortium of compost bioactivator used were Bacillus sp. S43, Bacillus cereus strains of IARIMB-6, Bacillus cereus strains TS11, Alcaligenes faecalis strains ZJUTBX11, Bacillus sp. 13847, Stenotrophomonas sp. S169-III-5, Alcaligenes faecalis strains KH-48 and Bacillus cereus strain Y22 by a comparison of $1: 1: 1: 1: 1: 1: 1: 1$. The results showed that bioactivator consortium was able to degrade OPEFB which on $\mathrm{P} 4$ (OPEFB + chicken manure + consortium isolate) reduced organic $\mathrm{C}$ from 50.1 to 34.5 , increased total nitrogen from 0.73 to 1.35 and reduced the $\mathrm{C} / \mathrm{N}$ ratio from 37.11 to 25.56 and produced compost phytonutrients and not phytotoxicity.
\end{abstract}

Keywords: Bioactivator, consortium, composting, empty bunch of palm oil

\begin{abstract}
ABSTRAK
Limbah tandan kosong kelapa sawit (TKKS) merupakan limbah padat kelapa sawit terbanyak. TKKS telah sering diolah menjadi pupuk kompos dengan penambahan aktivator tertentu. Diharapkan dengan penambahan bioaktivator konsortium selulolitik proses pengomposan TKKS dapat lebih cepat dan kompos yang dihasilkan memiliki kandungan hara yang baik. Penelitian ini bertujuan untuk mengetahui kemampuan bioaktivator bakteri konsorsium selulolitik dalam mendegradasi TKKS skala laboratorium inkubasi selama 30 hari. Konsorsium bioaktivator kompos yang digunakan adalah Bacillus sp. S43, Bacillus cereus strain IARI-MB-6, Bacillus cereus strain TS11, Alcaligenes faecalis strain ZJUTBX11, Bacillus sp. 13847, Stenotrophomonas sp. S169-III-5, Alcaligenes faecalis strain KH-48 dan Bacillus cereus strain Y22 dengan perbandingan 1:1:1:1:1:1:1:1. Hasil penelitian menunjukkan bioaktivator konsorsium mampu mendegradasi TKKS yang pada P4 (TKKS + kotoran ayam + isolat konsorsium) menurunkan C-organik dari 50,1 menjadi 34,5, meningkatkan $\mathrm{N}$-total dari 0,73 menjadi 1,35 dan menurunkan rasio $\mathrm{C} / \mathrm{N}$ dari 37,11 menjadi 25,56 , serta menghasilkan kompos bersifat fitonutrien dan tidak bersifat fitotoksisitas.
\end{abstract}

Kata Kunci: Bioaktivator, konsorsium, pengomposan, tandan kosong kelapa sawit, 


\section{PENDAHULUAN}

Perkebunan kelapa sawit di Riau mencapai 2,4 juta hektare (ha). Limbah padat perkebunan kelapa sawit terbanyak adalah limbah tandan kosong kelapa sawit (TKKS) yaitu sebanyak 23\% dalam 1 ton pemanenan kelapa (Dini et al. 2018). Alternatif pengolahan TKKS yang relatif murah dan mudah adalah diolah menjadi kompos (Siddiquee et al. 2017). Secara alami pengomposan berlangsung selama \pm 4-6 bulan. Proses pengomposan bisa dipercepat dengan cara penambahan aktivator (Okalia et al. 2018).

Zainal et al. (2018), melaporkan bahwa pengomposan TKKS menggunakan bioaktivator Bacillus subtilis (CPO1) dan Bacillus cereus (AA8), mampu dipercepat dalam kondisi aerobik. Perlakuan menggunakan kultur tunggal Bacillus subtilis $1 \times 10^{12}$ memiliki nilai rasio $\mathrm{C} / \mathrm{N}$ yaitu 17 , dan menggunakan Bacillus cereus $1 \times 10^{12}$ nilai rasio $\mathrm{C} / \mathrm{N}$ nya adalah 18,8 setelah inkubasi 25 hari. Penelitian dari Trisakti et al. (2018), menyatakan bahwa dalam pengomposan TKKS selama 40 hari mendapatkan rasio C/N 12,15, N 1,96, P 0,58 dan K 0,95.

Linda et al. (2016), melaporkan pengomposan jerami padi menggunakan konsorsium bakteri bioaktivator selulolitik inkubasi 6 minggu mendapatkan penurunan C-organik sebanyak 63,71 \% sedangkan kontrol hanya dapat menurunkan 37,33 \% dan mendapatkan nilai rasio C/N 26,50 sedangkan kontrol 37,36. Pupuk kompos TKKS memiliki kelebihan yaitu memperbaiki struktur tanah dari padat menjadi longgar, membantu larutnya unsur-unsur hara yang dibutuhkan oleh tanaman, meresap dan tidak mudah tercuci oleh air, serta bisa diaplikasikan di semua musim (Trisakti et al. 2018).

Penelitian mengenai pengomposan TKKS telah banyak dilakukan, tetapi untuk mendapatkan kompos TKKS yang kaya dengan nutrisi dengan proses yang cepat perlu dikaji lebih jauh. Penelitian ini bertujuan untuk melihat kemampuan activator bakteri konsortium selulolitik dalam mendegradasi TKKS pada kualitas kompos TKKS dengan waktu inkubasi selama 30 hari.

\section{METODE PENELITIAN}

Penelitian ini dilaksanakan pada bulan Desember 2018-April 2019 di Laboratorium Mikrobiologi, Fakultas Matematika dan Ilmu Pengetahuan Alam (FMIPA) dan di Jalan Buraq, Pondokan Tiga Dara. Peremajaan isolat bakteri Bacillus sp. S43, Bacillus cereus strain IARI-MB-6, Bacillus cereus strain TS11, Alcaligenes faecalis strain ZJUTBX11, Bacillus sp. 13847, Stenotrophomonas sp. S169-III-5, Alcaligenes faecalis strain KH-48 dan Bacillus cereus strain Y22 dilakukan dengan cara diinokulasikan secara pourplate pada medium nutrient agar (NA), lalu diinkubasi pada suhu ruang selama 24 jam. Selanjutnya masingmasing isolat bioaktivator diinokulasikan sebanyak satu ose ke dalam medium 
nutrient broth (NB) $50 \mathrm{~mL}$ dan kemudian diinkubasi pada shaker incubator dengan kecepatan $150 \mathrm{rpm}$ selama $18 / 19$ jam pada suhu $27^{\circ} \mathrm{C}$. Lalu, dilakukan pengenceran hingga didapatkan populasi bakteri $10^{8} \mathrm{cfu} / \mathrm{mL}$ dan setelah itu semua inokulum bioaktivator digabung/dikonsorsium dengan rasio 1:1 (Kavitha et al. 2013).

Persiapan selanjutnya adalah persiapan TKKS yang diambil dari Perkebunan Kelapa Sawit PT. Perkebunan Nusantara V, Sei. Galuh, Kab. Kampar, Riau. TKKS yang digunakan untuk proses pengomposan dilakukan pencacahan dengan mesin pencacah hingga ukuran menjadi lebih kecil $( \pm 5-10 \mathrm{~cm})$ dan selanjutnya dikeringanginkan sebelum digunakan. Lalu juga dilakukan persiapan kotoran ayam yang diambil dari peternakan ayam petelur di jalan Teropong, Pekanbaru. Proses pengomposan TKKS dalam penelitian ini menggunakan 4 perlakuan dan 5 ulangan dengan formula sebagai berikut P1 $($ kontrol $)=1 \mathrm{~kg}$ TKKS, P2 $=1 \mathrm{~kg}$ TKKS +450 gr kotoran ayam, P3 = $1 \mathrm{~kg}$ TKKS $+50 \mathrm{~mL}$ isolat konsortium, $\mathrm{P} 4=1 \mathrm{~kg}$ TKKS +450 gr kotoran ayam $+50 \mathrm{~mL}$ isolat konsortium. Masing-masing perlakuan diaduk hingga tercampur rata dan ditambahkan aquades hingga kelembaban 55-65 \% (Trisakti et al. 2018). Bahan yang telah teraduk rata, masing-masing dimasukkan ke dalam plastik hitam ukuran $10 \mathrm{~kg}$. Semua perlakuan diinkubasi selama 30 hari di bawah naungan dan ditutup dengan terpal agar tidak terkena hujan. Selama proses pengomposan berlangsung, kelembaban kompos dijaga dengan cara penyiraman dan pembalikan sekali tiga hari (Harahap et al. 2015).

Selama inkubasi 30 hari, masing-masing perlakuan dilakukan analisis beberapa parameter untuk mengetahui kematangan dan kualitas kompos. Pengumpulan data dalam penelitian ini dilakukan dengan menganalisis/mengukur beberapa parameter seperti parameter kimia berupa pengukuran kandungan karbon organik dengan metode loss on ignition, nitrogen total dengan metode kjeldahl dan rasio $\mathrm{C} / \mathrm{N}$ (pada hari ke- 0 dan 45), parameter fisika berupa pengukuran kandungan air, pengamatan warna, bau (pada hari ke- 0 dan 45) dan analisis parameter biologi yaitu pengecekan bakteri patogen coliform dan uji perkecambahan biji (pada hari ke-30). Pengecekan jumlah bakteri patogen coliform dilakukan dengan metode pour plate menggunakan media agar spesifik yaitu endo agar dan pada uji perkecambahan biji dilakuakan dengan cara setiap sampel kompos dicampur air suling 1:10 w/v, diaduk dan dibiarkan selama 30 menit, kemudian disaring. Ekstrak air masing-masing sampel digunakan untuk perkecambahan kacang hijau (Vigna radiata) menggunakan petri dish. Untuk perlakuan kontrol biji dikecambahkan dalam air suling tanpa dicampur dengan ekstrak air kompos. Keberhasilan perkecambahan kacang hijau (Vigna radiata) dihitung dengan rumus 


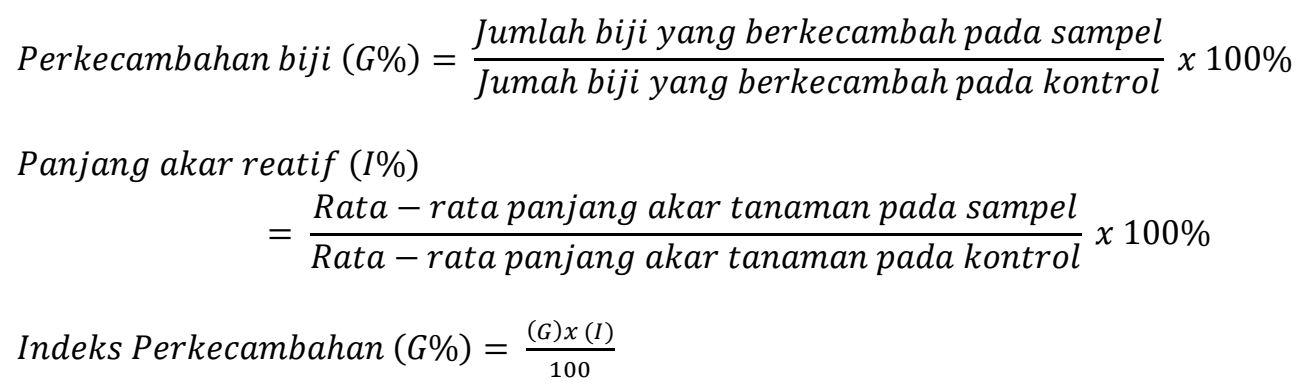

\section{HASIL DAN PEMBAHASAN}

\section{Parameter Kimia Kompos TKKS}

Parameter kimia kompos yang dianalisa adalah parameter C-organik, Ntotal dan rasio $\mathrm{C} / \mathrm{N}$. Hasil dari pengukuran parameter kimia kompos 0 hari dan 30 hari, didapatkan bahwa terjadinya penurunan $\mathrm{C}$-organik, peningkatan $\mathrm{N}$-total dan penurunan rasio $\mathrm{C} / \mathrm{N}$ sebagaimana disajikan pada Tabel 1. C-organik kompos untuk semua perlakuan mengalami penurunan, dengan yang terendah yaitu P4 hingga 34,5 setelah inkubasi 30 hari. Hal ini diduga disebabkan karena pada P4 dilakukan penambahan aktivator yang lebih banyak dari perlakuan lainnya yaitu gabungan inokulum bioaktivator konsorsium selulolitik dan kotoran ayam, akibatnya lebih banyak mikroorganisme pengurai yang menggunakan karbon sebagai sumber energi untuk aktivitas metabolismenya, sehingga C-organik menjadi turun. Penurunan C-organik pada penelitian ini lebih rendah dari penelitian Kavitha et al. (2013), yang menggunakan aktivator Bacillus sp., Streptomyces sp., dan Phanerochaete chrysosporiym yang dikonsortium ditambah pupuk kandang dan limbah cair kelapa sawit, memiliki nilai C-organik 23,8 namun dengan lama pengomposan 90 hari.

Semua perlakuan kompos pada penelitian ini mengalami kenaikan N-total. Kenaikan N-total tertinggi terdapat pada P4 yaitu mencapai 1,35, selanjutnya P3 1,25, P2 1,14 dan P1 0,81. P4 yang mengalami kenaikan N-total lebih tinggi dari perlakuan yang lain, hal ini disebakan karena proses dekomposisi TKKS oleh mikroorganisme mengubah ammonia menjadi nitrit.

Tabel 1. Nilai C-organik, N-total dan rasio C/N kompos TKKS setelah inkubasi 30 hari

\begin{tabular}{cccccccccc}
\hline & \multicolumn{4}{c}{ C-organik } & \multicolumn{3}{c}{ N-total } & \multicolumn{2}{c}{ Rasio C/N } \\
\cline { 2 - 9 } Perlakuan & 0 & 30 & Penurunan & 0 & 30 & Kenaikan & 0 & 30 \\
\cline { 2 - 9 } & hari & Hari & $(\%)$ & Hari & hari & $(\%)$ & hari & Hari \\
P1 & 50,3 & 47,73 & 5,11 & 0,69 & 0,81 & 17,4 & 72,90 & 58,93 \\
P2 & 50,1 & 34,7 & 30,74 & 0,7 & 1,14 & 62,86 & 71,57 & 30,44 \\
P3 & 50,2 & 37,6 & 25,1 & 0,7 & 1,25 & 78,57 & 71,71 & 30,08 \\
P4 & 50,1 & 34,5 & 31,14 & 0,73 & 1,35 & 84,93 & 68,63 & 25,56 \\
\hline
\end{tabular}


Selain itu, pada P4 yang ditambahkan bakteri bioaktivator konsorsium selulolitik diketahui memiliki potensi dalam fiksasi $\mathrm{N}$ (Linda et al. 2016). Penyebab lainnya adalah diduga karena pada perlakuan P4 ini menggunakan kotoran ayam yang kaya akan sumber N. Menurut Yulipriyanto (2006), salah satu ciri kotoran ayam adalah memiliki kandungan amoniak, N, P dan K yang cukup tinggi. Hal ini menyebabkan P4 mengalami kenaikan N-total yang cukup tinggi daripada perlakuan lainnya. Hasil nilai N-total pada penelitian ini, lebih rendah dari penelitian Harahap et al. (2015), yang melaporkan N-total yang didapat pada pengomposan TKKS sebanyak $1 \mathrm{~kg}$, dengan penambahan aktivator jamur Trichoderma harzianum $50 \mathrm{~mL}$ dan penambahan kotoran ayam $450 \mathrm{gr}$ dengan lama inkubasi 5 minggu yaitu 2,07.

Hasil penurunan rasio $\mathrm{C} / \mathrm{N}$ tertinggi berturut-turut adalah pada perlakuan $\mathrm{P} 4$ menurunkan rasio $\mathrm{C} / \mathrm{N}$ hingga 25,56, sedangkan $\mathrm{P} 3=30,08, \mathrm{P} 2=30,44$ dan $\mathrm{P} 1=58,93$. Penurunan rasio $\mathrm{C} / \mathrm{N}$ pada $\mathrm{P} 4$ yang cukup jauh dari perlakuan lainnya, disebabkan karena $\mathrm{P} 4$ memiliki nilai C-organik yang rendah dari perlakuan lain serta memiliki nilai $\mathrm{N}$-total yang tinggi dari perlakuan lainnya. Tinggi rendahnya kandungan C-organik dan N-total pada $\mathrm{P} 4$, disebabkan karena pengaruh penambahan dari bioaktivator konsortium selulotik dan penambahan kotoran ayam. Nilai rasio $\mathrm{C} / \mathrm{N}$ pada penelitian ini lebih baik dari pada penelitian Widodo et al. (2017), yang melaporkan bahwa pengomposan TKKS selama 12 minggu dengan pemberian aktivator yaitu urea, mendapatkan nilai rasio $\mathrm{C} / \mathrm{N}$ nya berkisar antara 27,64-50,20. Nilai rasio C/N pada penelitian ini belum memenuhi SNI (1020). Agar didapatkan kompos TKKS yang sesuai SNI, perlu dilakukan penelitian lebih lanjut mengenai optimasi inokulum bioaktivator konsorsium dan lama inkubasi.

\section{Parameter Fisika Kompos TKKS}

Parameter yang diamati pada parameter fisika adalah warna dan tekstur serta bau kompos. Pengamatan warna kompos pada penelitian ini, dibandingkan atau diamati dengan menggunakan acuan munsell soil colour chart 10 YR. Warna kompos dari penelitian ini mengalami perubahan menjadi lebih gelap, dengan P4 yang berwarna paling gelap diantara kompos yang lain seperti pada Gambar 1 .

Kompos pada P4 berwarna coklat keabu-abuan sangat gelap atau mulai kehitaman. Hal ini menandakan bahwa kompos sudah mulai matang, disusul oleh P2, P3 dan P1 yang belum matang. Kompos TKKS mengalami perubahan tekstur setelah inkubasi 30 hari. P4 memiliki partikel lebih halus dari perlakuan yang lain, disusul oleh P2, P3 dan P1. Pengomposan mengalami perubahan warna menjadi kehitaman, hal ini disebabkan karena berlangsungnya transformasi bahan organik dan pembentukan zat humus (Kusmiyarti 2013). 


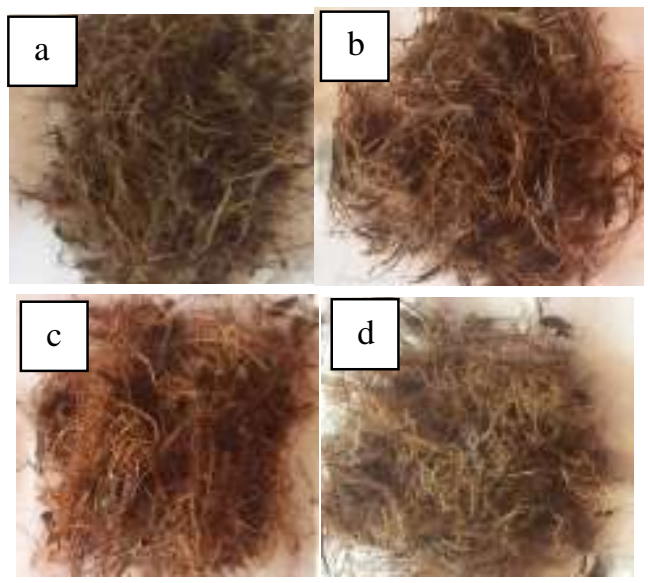

Gambar 1. Warna kompos TKKS dengan variasi perlakuan setelah inkubasi 30 hari : (a) P4, (b) P2,(c) P3 dan (d) P1 (Kontrol)

\section{Parameter Biologi Kompos TKKS}

Pada paremeter bilogi dilakukan uji perkecambahan biji kacang hijau, yang bertujuan untuk melihat kematangan kompos, fitotoksisitas kompos dan kandungan nutrisi kompos. Pengujian perkecambahan biji kacang hijau yang diinkubasi selama 72 jam, didapatkan hasil bahwa kompos yang diberi penambahan bioaktivator mengandung fitonutrien yang dibuktikan dengan panjang akar relatif kompos yang diberi perlakuan P2, P3 dan P4 lebih tinggi dari pada kontrol. Hasil uji perkecambahan P2, P3 dan P4 memiliki nilai panjang akar relatif yaitu P2 $122 \%$, P3 $132 \%$ dan P4 $142 \%$, sedangakan kontrol $100 \%$. Menurut Kheong et al. (2010), menyatakan bahwa kompos yang dapat merangsang pertumbuhan akar dikategorikan kaya menghasilkan fitonutrien. Kompos pada penelitian ini meskipun memiliki nilai rasio $\mathrm{C} / \mathrm{N}$ yang belum memenuhi standar SNI, namun pada uji perkecambahan didapatkan bahwa kompos pada penelitian ini dapat merangsang pertumbuhan akar yang menandakan kompos tersebut mengandung fitonutrien. Berdasarkan hasil ini dapat dikategorikan kompos pada penelitian ini sudah aman digunakan pada tanaman. Pada uji perkecambahan juga didapatkan nilai indeks perkecambahan disemua perlakuan memiliki nilai $\geq 80 \%$ seperti pada Gambar 2 .

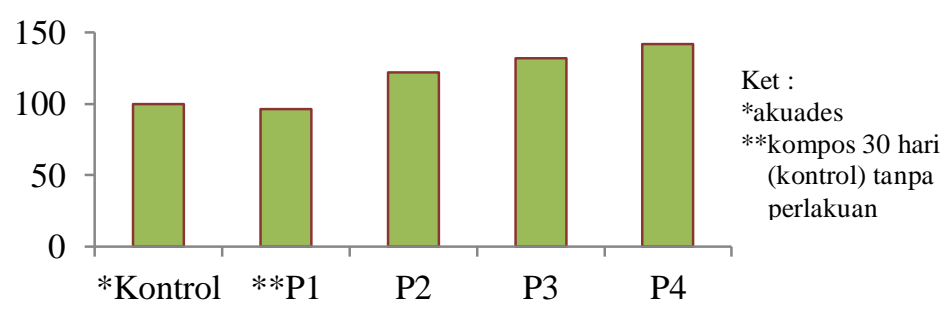

Gambar 2. Persentase indeks perkecambahan (GI\%) biji kacang hijau (Vigna radiata) menggunakan ekstrak dari kompos TKKS setelah 72 jam inkubasi 
Nilai GI \% tertinggi pada penelitian ini terdapat pada perlakuan $\mathrm{P} 4=142 \%$ dan selanjutnya P3=132\%, P2=122 \%, kontrol 100\% dan P1 $96 \%$. Perlakuan kompos yang digunakan dalam analisis parameter biologi pada penelitian ini belum mencapai target SNI, namun berdasarkan hasil indeks perkecambahan diketahui bahwa kompos telah matang dan dan tidak bersifat fitotoksisitas dikarenakan memiliki nilai GI\% lebih dari $80 \%$. Hal ini sesuai menurut Selim et al. (2012), nilai GI\% $\geq 80 \%$ menunjukkan bahwa fitotoksisitas kompos telah hilang dan kompos telah matang dan apabila kompos belum matang, akan terdapat senyawa fitotoksik seperti senyawa fenol, etilen, amonia dan asam organik yang dapat menghambat perkecambahan biji dan perpanjangan dari akar benih.

\section{KESIMPULAN}

Dari hasil penelitian pada P4 (TKKS + $50 \mathrm{~mL}$ inokulum bioaktivator + kotoran ayam) diketahui bahwa bioaktivator mendegradasi TKKS yang menurunkan C-organik $(34,5)$, menaikkan $\mathrm{N}$-total $(1,35)$ dan menurunkan rasio C/N (25,56) dengan waktu inkubasi 30 hari. Hasil uji perkecambahan menunjukkan bahwa kompos telah matang, tidak fitotoksisitas dan kaya fitonutrien. Perlakuan P4 dapat dikembangkan untuk pengomposan tandan kosong kelapa sawit.

\section{DAFTAR PUSTAKA}

Dini, I.R., Wawan, W., Hapsoh, H., Sriwahyuni, S., 2018. Isolation and Identification of Cellulolytic and Lignolytic Bacteria from the Gut Oryctes rhinoceros L. Larvae Decomposition of Oil Palm Empty Fruit Bunches. Indones. J. Agric. Res. 1, 193-203. https://doi.org/10.32734/injar.v1i2.314

Harahap, R.T., Sabrina, T., Marbun, P., 2015. Penggunaan Beberapa Sumber dan Dosis Aktivator Organik Untuk Meningkatkan Laju dekomposisi Kompos Tandan Kosong Kelapa Sawit. J. Online Agroekoteknologi. ISSN No. 2337-6597 3, 581-589.

Kavitha, B., Jothimani, P., Rajannan, G., 2013. Empty Fruit Bunch- a Potential Organic Manure for Agriculture. Int. J. Sci. Environ. Technol. 2, 930-937.

Kheong, L.V., Rahman, Z.A., Musa, M.H., Hussein, A., 2010. Empty fruit bunch application and oil palm root proliferation. J. Oil Palm Res. 22, 750757.

Kusmiyarti, T.B., 2013. Kualitas Kompos dari Berbagai Kombinasi Bahan Baku Limbah Organik. Agrotrop J. Agric. Sci. 3, 83-92.

Linda, T.M., Mutalib, S.A., Surif, S., 2016. Degradation of Cellulose and Hemicellulose in Rice Straw by Consortium Bacteria Cellulolytic. Appl. 
Sci. Technol. 1, 531-536.

Okalia, D., Nopsagiarti, T., Ezward, C., 2018. Pengaruh Ukuran Cacahan Tandan Kosong Kelapa Sawit Terhadap Karakteristik Fisik Kompos Tritankos (Triko Tandan Kosong). J. Agroqua 16, 132-142.

Selim, S.M., Zayed, M.S., Atta, H.M., 2012. Evaluation of Phytotoxicity of Compost During Composting Process. Nat. Sci. Sleep 10, 469-475.

Siddiquee, S., Shafawati, S.N., Naher, L., 2017. Effective composting of empty fruit bunches using potential Trichoderma strains. Biotechnol. Reports 13, 1-7. https://doi.org/10.1016/j.btre.2016.11.001

Trisakti, B., Mhardela, P., Husaini, T., Irvan, Daimon, H., 2018. Production of oil palm empty fruit bunch compost for ornamental plant cultivation. IOP Conf. Ser. Mater. Sci. Eng. 309, 0-8. https://doi.org/10.1088/1757899X/309/1/012094

Widodo, K., Sajarwan, A., Salampak, 2017. Percepatan Pengomposan Tandan Kosong Kelapa Sawit (TKKS) Dengan Pemberian Urea. J. AGRI PEAT 18, 113-124.

Yulipriyanto, H., 2006. Karakteristik Pengomposan Limbah Organik Kotoran Ayam Fase Thermofilik pada Lingkungan Alami Menggunakan Indore Pit Methode. Semin. Nas. MIPA 106-118.

Zainal, N.H., Aziz, A.A., Jalani, N.O.R.F., 2018. Rapid composting of empty fruit bunch using effective microbes. MPOB Inf. Ser. ISSN 1511-7871. 